\title{
AN EFFECT OF TAMOXIFEN (I.C.I. 46,474) ON THE SURFACE COAT OF THE LATE PREIMPLANTATION MOUSE BLASTOCYST
}

\author{
P. A. BLOXHAM, D. M. PUGH AND S. C. SHARMA \\ Department of Pharmacology, Faculty of Veterinary Medicine, \\ Trinity College, Dublin 2, Ireland
}

(Received 18th February 1975)

\begin{abstract}
Summary. The oral administration of Tamoxifen on Days 2, 3 and 4 after mating, or on Day 2 only, was found to prevent the oestrogendependent surface-coat change of the late preimplantation blastocyst in the mouse. It is suggested that this is an antioestrogenic manifestation and that it is, at least in part, responsible for the drug's known antifertility effect.
\end{abstract}

Holmes \& Dickson (1973) were prompted by reports of the increase in stickiness of the blastocyst after it sheds the zona pellucida, but before it implants, to seek a histochemical technique which would reveal this change in the surface coat. They showed a late preimplantation change in the ability of the coat to bind colloidal iron and suggested that this change is a functional requirement for the adhesion of the blastocyst to the uterine wall.

Tamoxifen (I.C.I. 46,474: trans 1[p-(2-dimethylaminoethoxy)-phenyl]-1, 2-diphenylbut-1-ene) is known to be an orally active, post-coital antifertility agent in mice and rats, exerting its effect by preventing implantation (Harper, 1971). It has been shown to have weakly oestrogenic and antioestrogenic properties in the rat, in which prevention of implantation is ascribed to the drug's antioestrogenic activity, but in mice Tamoxifen appears to be an oestrogen or pro-oestrogen (Harper \& Walpole, 1967). The confusion as to the dependence, if any, of the antifertility effect on either oestrogenic or antioestrogenic properties has been complicated further by evidence that the drug can have initial oestrogenic followed by antioestrogenic effects in mice (Emmens, 1971). It has recently been suggested that in rats Tamoxifen exerts its antifertility effect by an alteration of uterine metabolism (Major \& Heald, 1974). In an attempt to elucidate the mode of action of the drug's antifertility effect in mice we have studied its effect on the oestrogen-dependent surface-coat change of the blastocyst as part of a wider study on pharmacological aspects of the implantation process in mice.

Albino random-bred mice were maintained in a chamber with a standardized 10-hr dark period centred on 17.00 hours. Males were introduced at 12.00 hours and females were examined for vaginal plugs at 22.00 hours. A preliminary 
study confirmed that the mice were fully adapted to the artificial light/dark regimen as assessed by normality of oestrous cycles, while hourly checks throughout the 10-hr dark period then revealed that mating almost invariably occurred between 16.00 and 18.00 hours. In determining the precise time for killing the mice so as to collect ova of a known age, mating was considered to have taken place at 17.00 hours on Day 0 . The mated mice were randomly allocated to four groups. In the control groups no treatment was given and four mice were killed at $89 \mathrm{hr}$ and four mice at $96 \mathrm{hr}$ after mating. The treated mice received either $0.3 \mathrm{ml}$ of $0.5 \%(\mathrm{w} / \mathrm{v})$ aqueous Tween 80 (four animals) or 0.3 $\mathrm{ml}$ of solution of $0.1 \mathrm{mg}$ Tamoxifen $/ \mathrm{ml}$ in the Tween vehicle (six animals) to give a mean dose rate of $1 \mathrm{mg} / \mathrm{kg} /$ day. The doses were given orally at 10.00 hours on Days 2, 3 and 4, and the mice were killed $96 \mathrm{hr}$ after mating. Blastocysts were collected by reverse flushing of the uterine horns with the mouse eggculture medium of Whittingham (1971) and were examined in the fresh state to determine whether the late preimplantation change in shape from spherical to elongate had taken place. The eggs were fixed for $24 \mathrm{hr}$ in $10 \%$ buffered neutral formalin before being air-dried onto slides and stained according to the method of Holmes \& Dickson (1973) with colloidal iron converted to Prussian blue by equal volumes of $2 \%$ potassium ferrocyanide and $2 \%$ hydrochloric acid, except that $1 \%$ Neutral Red was used as the counterstain. This technique, the results of which are unaffected by the presence or absence of the zona pellucida, stains eggs red before they undergo surface-coat change, after which the binding of dialysed iron to the trophoblast surface becomes evident as a blue deposit. Unfertilized eggs were disregarded. At $89 \mathrm{hr}$ all control eggs (42) were red and spherical in shape, while by $96 \mathrm{hr}$ all control eggs (39) stained blue and had elongated. The 40 eggs from those mice which received vehicle alone were blue and elongated, while the 52 eggs from mice treated with Tamoxifen were still red and spherical at $96 \mathrm{hr}$.

In a further experiment in which the treated group received only a single oral dose of $0.2 \mathrm{mg}$ Tamoxifen $/ \mathrm{kg}$ on Day 2, 35 eggs from four females were red and round at $96 \mathrm{hr}$, while 28 eggs from three control females were elongated and blue.

The results from the control groups confirm that the staining technique is able to demonstrate that a change takes place in the surface coat of the preimplantation blastocyst between 89 and $96 \mathrm{hr}$ after fertilization. The lack of blue stain in the eggs from the Tamoxifen-treated group indicated that the surface coat had not changed. Forty elongated $96-\mathrm{hr}$ eggs from untreated mice were incubated in Whittingham's medium containing $0.1 \mathrm{mg}$ Tamoxifen $/ \mathrm{ml}$ for $12 \mathrm{hr}$, and still stained blue, indicating that the drug did not remove the surface coat or interfere with the expected staining reaction of the eggs.

The importance of various hormones and autacoids (Marcus \& Shelesnyak, 1968; Johnson, 1972; Grant \& McLaren, 1973) to implantation has been described for several species. Oestrogen levels have been shown to rise on Day 4 of pregnancy in the mouse (McCormack \& Greenwald, 1974), reaching a peak before implantation (P. A. Bloxham, D. M. Pugh \& S. C. Sharma, unpublished data). This postovulatory oestrogen surge is believed to be necessary for implantation to take place, and it has been proposed that one of its functions may 
be the induction of the surface coat change, so facilitating the attachment phase of implantation (Holmes \& Dickson, 1973).

We therefore consider that Tamoxifen prevents the surface-coat change of the blastocyst that is induced by the postovulatory oestrogen peak. The consequent failure of the trophoblast to become sticky would presumably be detrimental for attachment, and the known antifertility action of Tamoxifen in impeding implantation may therefore be due to its antioestrogenic effect on the surfacecoat change. At this stage it is not possible to say whether this effect is mediated directly or indirectly, i.e. by modifying oestrogen uptake into the blastocyst or elsewhere or by a suppression of release of endogenous oestrogen.

This work is in part supported by a Wellcome Veterinary Research Training Scholarship (P.A.B.). The I.C.I. 46,474 was generously donated by Dr A. L. Walpole of I.C.I., Alderley Park, Cheshire.

\section{REFERENCES}

Emagns, G.W. (1971) Compounds exhibiting prolonged antioestrogenic and antifertility activity in mice and rats. F. Reprod. Fert. 26, 175-182.

Grant, P.S. \& McLaren, A. (1973) Egg implantation and deciduoma induction in cyclic mice after treatment with progestogens and oestradiol. 7. Reprod. Fert. 34, 415-421.

HARPER, M.J.K. \& Walpole, A.L. (1967) A new derivative of triphenylethylene: effect on implantation and mode of action in rats. F. Reprod. Fert. 13, 101-119.

Holmes, P.V. \& Dickson, A.D. (1973) Estrogen induced-surface coat and enzyme changes in the implanting mouse blastocyst. F. Embryol. exp. Morph. 29, 639-645.

Johnson, M.H. (1972) The distribution of a blastokinin-like uterine protein studied by immune fluorescence. Fert. Steril. 23, 929-939.

McCormack, J.T. \& Greenwald, G.S. (1974) Evidence for a pre-implantation rise in oestradiol-17 $\beta$ levels on Day 4 of pregnancy in the mouse. F. Reprod. Fert. 41, 297-301.

MajOR, J.S. \& Heald, P.J. (1974) The effect of I.C.I. 46,474 on ovum transport and implantation in the rat. F. Reprod. Fert. 36, 117-124.

Marcus, G.J. \& Shelesnyak, M.C. (1968) Studies on the mechanism of nidation. XXXIII. Coital elevation of uterine histamine content. Acta endocr., Copenh. 57, 136-141.

Whitringham, D.G. (1971) Culture of mouse ova. F. Reprod. Fert., Suppl. 14, 7-21. 